\title{
ISOLASI DAN IDENTIFIKASI JAMUR PENGHASIL MIKOTOKSIN PADA BIJI KAKAO KERING YANG DIHASILKAN DI FLORES-LEMBATA
}

\author{
Emilia S.A. Wangge \\ Emilia_wangge@yahoo.co,id \\ Program Studi Agroteknologi, Fakultas Pertanian-Universitas Flores
}

\begin{abstract}
A study entitled "Isolation and Identification of Mycotoxin-producing Fungi on Cocoa Beans Produced in Flores and Lembata" was done in order to know the population and species of fungi and to know the concentration of mycotoxin in the dried cocoa beans. The dry cocoa beans used in this study were collected from several locations in Flores. Isolation of the fungi was done using Sabouraud Dextrosa Agar (SDA). Results of this study showed that, there were several fungi were found in the dried cocoa beans produced in Flores, namely Aspergillus niger, A. flavus, A. parasiticus, A. fumigatusandMucor sp.
\end{abstract}

\section{PENDAHULUAN}

Kakao (Theobroma cacao L.) merupakan salah satu komoditas ekspor yang dapat memberikan kontribusi untuk peningkatan devisa. Indonesia merupakan negara pengekspor kakao terbesar ketiga di dunia dengan kontribusi sebesar $13 \%$ setelah Pantai Gading (38\%) dan Ghana (19\%) (Wahyudi et al.,2008). Permintaan dunia terhadap komoditas kakao semakin meningkat dari tahun ke tahun. Hingga tahun 2011, ICCO (International Cocoa Organization) memperkirakan produksi kakao dunia akan mencapai 4,05 juta ton, sementara konsumsi akan mencapai 4,1 juta ton, sehingga akan terjadi defisit sekitar 50 ribu ton per tahun (Suryani, 2007). Kondisi ini merupakan suatu peluang yang baik karena Indonesia berpotensi untuk menjadi produsen utama kakao dunia.
Kualitas biji kakao yang diekspor oleh Indonesia dikenal rendah. Di Amerika Serikat, biji kakao Indonesia selalu mendapatkan penahanan (automatic detention) karena sering ditemukan jamur, kotoran, serangga dan benda asing lainnya (Rahmadi, 2008). Banyak faktor yang mempengaruhi mutu biji kakao kering, diantaranya 75 $\%$ oleh teknik pengolahan dan $25 \%$ oleh jenis kakao, situasi dan kondisi daerah produksi (Badrun, 1991).

Tekhnik pengolahan biji kakao seperti fermentasi dan pengeringan berperan dalam menentukan mutu hasil. Biji kakao rentan terhadap pembusukan jamur. Minifie (1999) menyatakan produk biji kakao dapat ditumbuhi jamur dan jamur yang sering ditemui pada biji kakao yang proses penanganan dan pengolahan yang tidak tepat adalah jamur dari genera Aspergillus, Mucorsp, 
Emilia: Isolasi dan identifikasi jamur penghasil mikotoksin pada biji kakao kering yang dihasilkan di Flores-Lembata

Penicilium, dan Rhyzopus (Aroyeun dan Adegoke, 2006).

Dalam genera Aspergillus, tiga spesies yang merupakan perhatian utama bagi kesehatan masyarakat adalah A. flavus, A. parasiticus, dan A. ochraceus (Cotty, 1997; Moss, 2002). Selain A. flavus dan A. parasiticus, A. nigerjuga membahayakan karena dapat menghasilkan mikotoksin pada biji kakao kering (Rahmadi dan Fleet, 2007). Demikian pula Mucor sp dapat menghasilkan mikotoksin jenis Alimentary Toksik Aleukia (ATA) (Siagian, 2002).Jamur yang ada pada bahan pangan dapat menghasilkan toksin. Hampir semua jamur memproduksi toksin, yang disebut mikotoksin (Pitt dan Hocking, 1997).

Keberadaan mikotoksin terutama aflatoksin dan okratoksin pada bahan makanan merupakan masalah ekonomi yang utama bagi negara eksportir, dan ini akan diperburuk oleh peraturan yang ketat dari negara pengimpor yang sangat memperhatikan aspek kesehatan. Amerika Serikat melalui Badan administrasi makanan dan obat-obatan (FDA) memberikan batasan konsentrasi aflatoksin untuk semua makanan adalah 20 ppb. Demikian pula Indonesia melalui badan pengawasan obat dan makanan (2004) memberikan batas maksimal kandungan mikotoksin pada makanan adalah 20 ppb. Konsumsi produk pangan yang terkontaminasi mikotoksin dapat menyebabkan terjadinya mikotoksikosis, yaitu gangguan kesehatan pada manusia dan hewan dengan berbagai bentuk perubahan klinis dan patologis, micslnva dapat menyebabkan penyakit 24 kanker hati, demam, pembengkakan otak, ginjal dan gangguan syaraf (Rahayu, 2006).

Flores merupakan salah satu dari puluhan pulau di Propinsi NTT, yang memiliki aneka komoditi perkebunan yang cukup baik. Di Flores dan Lembata terdapat 8 Kabupaten dengan aneka jenis tanaman komoditi perkebunan dan yang paling dominan dibudidayakan oleh para petani di Flores adalah kakao. Adapun produksi biji kakao yang dihasilkan oleh masingmasing kabupaten di Flores pada tahun 2007 adalah dari Kabupaten Manggarai Baratsebanyak 177 ton, Kabupaten Manggarai Timur sebanyak 311 ton, Kabupaten Ngada sebanyak 161 ton dan Kabupaten Nagekeo sebanyak 579 ton. Sedangkan produksi biji kakao di Kabupaten Ende sebanyak 2886 ton, Kabupaten Sikka sebanyak6682 ton, Kabupaten Flores Timursebanyak 651 ton dan Kabupaten Lembata sebanyak 49 ton (BPS NTT, 2011).

Berdasarkan produksi kakao di Flores dan Lembatadan bahaya kontaminasi jamur penghasil mikotoksin pada biji kakao kering maka penulis melakukan suatu penelitian untuk mengisolasi dan mengidentifikasi jamur yang terdapat pada biji kakao kering yang berasal dari berbagai daerah di Flores, serta meneliti tentang jamur apa yang dapat menghasilkan mikotoksin pada biji kakao kering.

\section{METODE PENELITIAN}

Penelitian ini dilakukan bulan Juni sampai bulan Agustus 2011. Isolasi dan identifikasi jamur dan pengujian kadar aflatoksin B1 dan Okratoksin A dilaksanakan di Laboratorium Ralai 
Emilia: Isolasi dan identifikasi jamur penghasil mikotoksin pada biji kakao kering yang dihasilkan di Flores-Lembata

Besar Veteriner Denpasar. Biji kakao kering yang digunakan dalam penelitian merupakan biji kakao kering yang dihasilkan di Flores yaitu Kabupaten Manggarai Timur, Kabupaten Manggarai Barat, Kabupaten Ngada,

Tabel 1. Lokasi Pengambilan Sampel dan Kode Sampel Biji Kakao Kering Terfermentasi yang Dihasilkan di Flores dan Lembata

\begin{tabular}{|c|c|c|c|}
\hline No & Kode Sampel & Lokasi & Kabupaten \\
\hline 1 & MB1 & Puspa Sari & Manggarai Barat \\
\hline 2 & MB2 & Lembor & Manggarai Barat \\
\hline 3 & MT1 & Sinar Mas & Manggarai Timur \\
\hline 4 & MT2 & Mborong & Manggarai Timur \\
\hline 5 & ND1 & Surya Mas & Ngada \\
\hline 6 & ND2 & Aimere & Ngada \\
\hline 7 & NK1 & Surya Indah & Nagekeo \\
\hline 8 & NK2 & Mbay & Nagekeo \\
\hline 9 & ED1 & Perdana & Ende \\
\hline 10 & ED2 & Kawi Indah & Ende \\
\hline 11 & SK1 & Kuda Mas & Sikka \\
\hline 12 & SK2 & Nita & Sikka \\
\hline 13 & FT1 & Belogili & Flores Timur \\
\hline 14 & FT2 & Tanjung Bunga & Flores Timur \\
\hline 15 & LB1 & Adonara & Lembata \\
\hline 16 & LB2 & Solor & Lembata \\
\hline
\end{tabular}

Tabel 2 Lokasi Pengambilan Sampel dan Kode Sampel Biji Kakao Kering tidak Terfermentasi yang Dihasilkan di Flores dan Lembata

\begin{tabular}{llll}
\hline No & Kode Sampel & Lokasi & Kabupaten \\
\hline 1 & MB3 & Welak & Manggarai Barat \\
3 & MB4 & Komodo & Manggarai Barat \\
4 & MT3 & Cikal & Manggarai Timur \\
5 & MT4 & Puspa & Manggarai Timur \\
6 & ND3 & Soa & Ngada \\
7 & ND4 & Bena & Ngada \\
8 & NK3 & Mauponggo & Nagekeo \\
9 & NK4 & Watu Api & Nagekeo \\
10 & ED3 & Wolosoko & Ende \\
11 & ED4 & Fajar Timur & Ende \\
12 & SK3 & Bintang Timur & Sikka \\
13 & SK4 & Bina Karya & Sikka \\
14 & FT3 & Nobo & Flores Timur \\
15 & FT4 & Boru & Flores Timur \\
16 & LB3 & Lomblen & Lembata \\
& & Konga &
\end{tabular}

Kabupaten Nagekeo, Kabupaten Ende, Kabupaten Sikka, Kabupaten Flores Timur dan Kabupaten Lembata. Lokasi pengambilan sampel dan kode sampel dapat dilihat pada Tabel 1 dan Tabel 2.

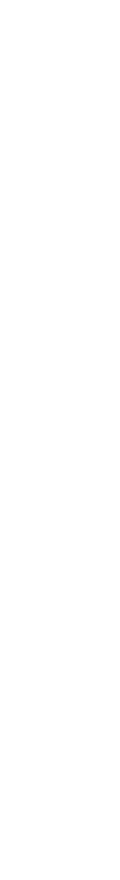


Emilia: Isolasi dan identifikasi jamur penghasil mikotoksin pada biji kakao kering yang dihasilkan di Flores-Lembata

Sampel yang digunakan dalam penelitian ini adalah biji kakao kering terfermentasi dan tidak terfermentasi yang dihasilkan di Flores.Sampel biji kakao kering tersebut merupakan biji kakao kering yang sudah diolah petani selama 3-5 hari dan lama penyimpanannya di gudang 2 (dua) minggu.

\section{Isolasi dan Identifikasi Jamur}

Isolasi jamur dilakukan dengan menggunakan media SDA (Sabouraud Dextrosa Agar). Proses pemurnian dilakukan dengan cara mengambil isolate jamur berumur tiga hari dalam kultur menggunakan cork borer berdiameter $0,5 \mathrm{~mm}$ kemudian dengan jarum ose isolat jamur diinokulasikan pada media SDA dan selanjutnya disimpan selama tiga hari dalam suhu kamar. Pemindahan isolat (pemurnian) diulang sebanyak tiga kali sampai isolat benar-benar murni dan diamati secara mikroskopis dan diidentifikasi. Proses identifikasi jamur berdasarkan ciri-ciri dan karakter morfologis secara makroskopis (visual) dan mikroskopis dilakukan di bawah mikroskop dengan pembesaran $400 \mathrm{x}$. Pewarnaan preparat untuk pengamatan pada mikroskop terdiri atas larutan Lactophenol Cotton Blue (pewarna jamur), (Cowan dan
Steel's, 1993). Sesuai dengan sifat-sifat jamur ; hifa, warna koloni, bentuk visikel, ciri-ciri sporangium atau sporangiofor, konidia, dan konidiofor. Identifikasi jamur dilakukan berdasarkan panduan Pitt dan Hocking (1997), Samson et al. (1995), dan Olds (1975).

\section{HASIL DAN PEMBAHASAN}

\section{A. Jenis Jamur pada Biji Kakao}

\section{Kering di Flores dan Lembata}

Berdasarkan hasil isolasi jamur pada media Sabouraud Dextrosa Agar (SDA), terdapat beberapa jenis jamur pada biji kakao kering yang dihasilkan di Flores. Koloni jamur ditempatkan dalam cawan Petri berisi media SDA kemudian dipilah-pilah berdasarkan morfologi dan warna. Inkubasi dilakukan pada suhu kamar $\left(25^{\circ} \mathrm{C}\right)$. Berdasarkan hasil isolasi dan identifikasi terdapat beberapa spesies jamur yang mengkontaminasi biji kakao kering di Flores yaitu Aspergillus niger, Aspergillus flavus, Aspergillus parasiticus, Aspergillus fumigatus dan Mucor sp.

Berdasarkan hasil pengamatan, secara makroskopis spesies A. niger menampakkan koloni kompak berwarna putih, dan kuning pada permukaan bawah koloni yang akan berubah 
Emilia: Isolasi dan identifikasi jamur penghasil mikotoksin pada biji kakao kering yang dihasilkan di Flores-Lembata

menjadi coklat gelap sampai hitam setelah terbentuk konidiospora.

Berdasarkan pengamatan secara mikroskopis bentuk badan buah $A$. niger dicirikan dengan vesikula berbentuk bulat hingga semi bulat. Konidia bulat hingga semi bulat, dan berwarna coklat tua.

Spesies A. flavus) secara makroskopis memiliki ciri koloninya pada saat muda berwarna putih, dan akan berubah menjadi berwarna hijau kekuningan setelah membentuk konidia. Secara mikroskopis ciri dari badan buah A. flavus adalah vesikula berbentuk bulat hingga semi bulat dan konidia berbentuk bulat hingga semi bulat.

Species A. parasiticus, memiliki ciri-ciri sebagai berikut : koloni hijau gelap, konidiofor dengan satu set sterigmata, bentuk visikelnya bulat (globular) dan pemukaan spora kasar (bergerigi). Spesies A. fumigatus, memiliki ciri-ciri koloni saat muda berwarna putih dan dengan cepat berubah menjadi hijau seiring dengan terbentuknya konidia. Konidiofor pendek, dan berwarna hijau (khusus pada bagian atas). Vesikula berbentuk gada.Konidia bulat hingga semi bulat, berdinding kasar. Mucor sp. memiliki koloni berwarna putih dan akhirnya berwarna kelabu, berwarna kuning dan halus, hifa tidak berseptat kadangkadang membentuk cabang, sporangiospora tumbuh pada seluruh bagian miselium, kolumela berbentuk bulat, silinder atau seperti buah advokad dan tidak membentuk stolon (Fardiaz, 1989).

\section{Populasi jamur pada biji kakao kering terfermentasi yang dihasilkan di Flores dan Lembata.}

Hasil penelitian menunjukkan pada setiap sampel yang diteliti terdapat lebih dari satu spesies jamur. Total populasi jamur yang terdapat pada sampel biji kakao kering terfermentasi asal Flores berkisar antara $140 \times 10^{2}$ $\mathrm{cfu} / \mathrm{g}$ sampai $320 \times 10^{2} \mathrm{cfu} / \mathrm{g}$. Total populasi jamur terendah terdapat pada sampel NK1 (Nagekeo 1) dan total populasi jamur tertinggi terdapat pada sampel MB1 (Manggarai Barat).

Berdasarkan Tabel 3 jumlah populasi jamur pada sampel MB1 lebih tinggi dari sampel lain yang diteliti, hal ini disebabkan karena proses fermentasi yang dilakukan oleh petani asal Manggarai Barat kurang tepat. Berdasarkan pengamatan di lapangan, proses fermentasi yang dilakukan oleh petani Manggarai Barat menggunakan alat yang kurang higienes dan waktu 
Emilia: Isolasi dan identifikasi jamur penghasil mikotoksin pada biji kakao kering yang dihasilkan di Flores-Lembata

yang kurang tepat. Wadah yang digunakan untuk proses fermentasi oleh para petani adalah karung-karung bekas mengisi pupuk atau hasil pertanian lainnya yang memungkinkan adanya kontaminasi mikroba yang tidak diinginkan. Rahmadi (2008) menyatakan titik kritis fermentasi adalah pada flora awal dimana terjadi cemaran bakteri pathogen dan jamur penghasil toksin.

Waktu fermentasi yang dilakukan tidak sesuai dengan waktu fermentasi yang ditetapkan. Lamanya waktu fermentasi yang dilakukan oleh petani Manggarai Barat adalah 30- 36 jam. Selama proses fermentasi, tidak dilakukan pembalikan/pengadukan sehingga cairan dari pulp tidak dapat keluar dengan baik. Hal ini menyebabkan bakteri penghasil spora dan jamur berfilamen muncul dan pada umumnya tidak disukai, karena beberapa diantaranya dapat memproduksi toksin. Proses fermentasi yang kurang tepat yang dilakukan para petani tersebut menyebabkan populasi jamur pada biji kakao menjadi sangat tinggi. Minifie (1999) menyatakan selama fermentasi terjadi proses yang kompleks sehingga memungkinkan biji kakao tersebut terserang jamur penghasil mikotoksin. Fristo (2009) menyatakan bahwa biji kakao kering yang difermentasi lebih rentan terserang jamur.

Wahyudi et al. (2008) menyatakan proses fermentasi yang dapat menghasilkan biji kakao berkualitas tinggi adalah sebagai berikut:

1. Buah hasil panen dibelah dan biji berselimut pulp dikeluarkan.

2. Biji dikumpulkan pada suatu wadah. Jenis wadah yang digunakan berupa keranjang yang dilapisi oleh daun, dan kontainer kayu. Pada umumnya, dasar kontainer memiliki lubang kecil untuk drainase dan aerasi.

3. Biji yang dimasukkan dalam kontainer tidak diisi secara penuh, sisakan $10 \mathrm{~cm}$ dari atas dan permukaan atas ditutupi dengan daun pisang yang bertujuan untuk menahan panas dan mencegah permukaan biji dari kekeringan.

4. Simpan kontainer di atas tanah atau di atas saluran untuk menampung pulp juices yang dihasilkan selama fermentasi (hasil degradasi pulp).

5. Fermentasi dalam kotak dapat dilakukan selama 2 - 6 hari, isi kotak dibalik tiap hari dengan memindahkannya ke kotak lain. 
Emilia: Isolasi dan identifikasi jamur penghasil mikotoksin pada biji kakao kering yang dihasilkan di Flores-Lembata

Tabel 3 Populasi Jamur yang Diisolasi dari berbagai Sampel Biji Kakao Kering Terfermentasi yang dihasilkan di Flores dan Lembata

\begin{tabular}{|c|c|c|c|c|c|c|c|}
\hline \multirow{2}{*}{ No } & \multirow{2}{*}{$\begin{array}{c}\text { Kode } \\
\text { Sampel }\end{array}$} & \multicolumn{5}{|c|}{ Jamur $\left(\times 10^{2} \mathrm{cfu} / \mathrm{g}\right)$} & \multirow{2}{*}{$\begin{array}{l}\text { Total } \\
\text { Jamur }\end{array}$} \\
\hline & & A. niger & A. flavus & A. fumigatus & A. parasiticus & Mucor sp. & \\
\hline 1 & MB1 & 240 & 40 & 0 & 20 & 20 & 320 \\
\hline 2 & MB2 & 100 & 40 & 0 & 40 & 40 & 220 \\
\hline 3 & MT1 & 0 & 60 & 70 & 60 & 40 & 230 \\
\hline 4 & MT2 & 0 & 50 & 80 & 40 & 20 & 190 \\
\hline 5 & ND1 & 90 & 0 & 80 & 40 & 30 & 240 \\
\hline 6 & ND2 & 110 & 0 & 70 & 40 & 20 & 240 \\
\hline 7 & NK1 & 60 & 0 & 60 & 0 & 20 & 140 \\
\hline 8 & NK2 & 40 & 0 & 100 & 0 & 20 & 160 \\
\hline 9 & ED1 & 200 & 40 & 70 & 0 & 0 & 310 \\
\hline 10 & ED2 & 110 & 50 & 0 & 0 & 0 & 160 \\
\hline 11 & SK1 & 60 & 60 & 80 & 30 & 0 & 230 \\
\hline 12 & SK2 & 80 & 20 & 30 & 30 & 0 & 160 \\
\hline 13 & FT1 & 80 & 40 & 50 & 0 & 0 & 170 \\
\hline 14 & FT2 & 100 & 50 & 60 & 0 & 0 & 210 \\
\hline 15 & LB1 & 100 & 30 & 0 & 80 & 0 & 210 \\
\hline 16 & LB2 & 70 & 40 & 0 & 70 & 0 & 180 \\
\hline
\end{tabular}

jamur terendah terdapat sampel ED3

Populasi jamur pada biji kakao kering yang tidak terfermentasi

Hasil penelitian menunjukan bahwa total populasi jamur pada biji kakao kering di Flores dan Lembata yang tidak terfermentasi berkisar antara $50 \times 10^{2} \mathrm{cfu} / \mathrm{g}$ sampai $130 \times 10^{2} \mathrm{cfu} / \mathrm{g}$ (Tabel 4).

$$
\text { Berdasarkan Tabel 4, }
$$
menunjukkan bahwa populasi jamur pada biji kakao yang tidak terfermentasi tertinggi terdapat pada sampel MT3 (Kabupaten Manggarai Timur) yaitu $130 \times 10^{2} \mathrm{cfu} / \mathrm{g}$, sedangkan populasi
(Kabupaten Ende) yaitu $50 \times 10^{2} \mathrm{cfu} / \mathrm{g}$. Total populasi jamur yang tinggi pada biji kakao pada sampel MT3 disebabkan karena proses pengeringan yang dilakukan petani kurang tepat. 
Emilia: Isolasi dan identifikasi jamur penghasil mikotoksin pada biji kakao kering yang dihasilkan di Flores-Lembata

Tabel 4 Populasi Jamur yang Diisolasi dari berbagai Sampel Biji Kakao Kering yang tidak Terfermentasi yang dihasilkan di Flores dan Lembata

\begin{tabular}{cccccccc}
\hline No & Kode & \multicolumn{3}{c}{ Jamur (x 10 cfu/g) } & Total \\
& Sampel & A. niger & A. flavus & A. fumigatus & A. parasiticus & Mucor sp. & Jamur \\
\hline 1 & MB3 & 40 & 10 & 0 & 20 & 20 & 90 \\
2 & MB4 & 40 & 10 & 0 & 10 & 10 & 70 \\
3 & MT3 & 10 & 20 & 80 & 0 & 20 & 130 \\
4 & MT4 & 0 & 20 & 60 & 0 & 10 & 90 \\
5 & ND3 & 30 & 20 & 50 & 0 & 20 & 120 \\
6 & ND4 & 20 & 30 & 40 & 0 & 20 & 110 \\
7 & NK3 & 0 & 0 & 40 & 20 & 20 & 80 \\
8 & NK4 & 0 & 0 & 40 & 10 & 20 & 70 \\
9 & ED3 & 20 & 10 & 0 & 20 & 0 & 50 \\
10 & ED4 & 10 & 10 & 0 & 40 & 0 & 60 \\
11 & SK3 & 30 & 20 & 60 & 0 & 0 & 110 \\
12 & SK4 & 20 & 20 & 60 & 0 & 0 & 100 \\
13 & FT3 & 10 & 10 & 30 & 0 & 20 & 70 \\
14 & FT4 & 20 & 20 & 40 & 0 & 10 & 90 \\
15 & LB3 & 60 & 0 & 10 & 0 & 0 & 70 \\
16 & LB4 & 40 & 0 & 20 & 0 & 0 & 60 \\
\hline
\end{tabular}

Hasil pengamatan, wadah untuk menjemur tidak higienes dan waktu pengeringan kurang sempurna. Wadah yang digunakan oleh para petani untuk menjemur biji kakao adalah terpal, karung atau tikar bekas. Selain itu faktor lain yang menyebabkan tingginya populasi jamur dari kabupaten Manggarai Timur adalah kurangnya sinar matahari pada waktu penjemuran. Manggarai Timur merupakan daerah dingin dan tingkat kelembaban yang tinggi dengan suhu berkisar $15-30{ }^{0} \mathrm{C}$ (BPS, 2011). Karena pengeringan yang kurang baik, maka kadar air pada biji kakao menjadi tinggi yaitu lebih dari
7,5\%. Hal ini menyebabkan biji kakao mudah terserang jamur. Pitt dan Hocking (1997) menyatakan kadar air bahan mempengaruhi daya tahan bahan terhadap serangan mikroba.

Pengeringan biji kakao yang paling baik adalah dibawah suhu $60^{\circ} \mathrm{C}$ atau dibawah terik sinar matahari.Pengeringan harus berlangsung cukup cepat untuk mencegah pertumbuhan jamur dan bakteri penghasil spora (Rahmadi, 2008).Adapun cara pengeringan yang perlu dilakukan oleh petani maupun pengusaha adalah penjemuran dibawah terik matahari secara penuh. Energi 
Emilia: Isolasi dan identifikasi jamur penghasil mikotoksin pada biji kakao kering yang dihasilkan di Flores-Lembata

untuk penguapan air pada biji kakao diperoleh dari radiasi sinar matahari. Secara teknis cara ini akan memberikan hasil yang baik, jika sinar matahari mempunyai intensitas yang cukup dan dapat dimanfaatkan secara maksimal. Lantai jemur dibuat dari bahan yang mempunyai sifat menyerap panas.Tebal tumpukan biji kakao di lantai jemur optimal.Pembalikkan biji kakao saat menjemur harus dilakukan agar dapat mencegah penyerapan ulang air dari permukaan lantai jemur ke dalam biji kakao (Wahyudi, 1992). Lebih lanjut dikatakan oleh Susanto (1994) bahwa penjemuran sebaiknya menggunakan model para-para (meja pengering) atau lantai semen. Model para-para menggunakan lantai jemur dari papan kayu atau anyaman bambu dan disangga dengan kaki-kaki lebih kurang 0,50 m dari permukaan tanah. Jika diperlukan, para-para dapat dilengkapi dengan penutup dari kain terpal atau plastik tembus sinar (transparan).Duncan et al. (1989) menyatakan model penjemuran dengan lantai semen berbeda dengan model para-para yaitu penjemuran dengan lantai semen mempunyai hamparan penjemuran langsung di atas permukaan tanah.Profil lantai jemur dibuat miring lebih kurang $5-7^{\circ}$ dengan sudut pertemuan di bagian tengahnya. Pinggiran lantai dilengkapi dengan saluran pembuangan air dan tiang-tiang penyangga untuk mengkaitkan plastik penutup (terpal).Saat hari hujan, biji kakao digundukkan di bagian tengah lantai dan ditutup dengan terpal.Teknik penjemuran yang umum, baik menggunakan model para-para maupun lantai semen, adalah menghamparkan biji kakao dengan tebal lapisan biji 3 - 5 cm (2 - 3 lapis biji atau lebih kurang 8 $10 \mathrm{~kg}$ biji basah per m2 luas lantai jemur).Cuaca dan frekuensi pembalikan biji sangat berpengaruh terhadap waktu dan kapasitas penjemuran.Saat cuaca cerah, dengan lama penyinaran $7-8$ jam per hari, waktu penjemuran antara 7 - 9 hari dengan pembalikan 1 - 2 jam sekali. Minifie (1999) menyatakan pengeringan merupakan faktor yang sangat penting dalam menghasilkan biji kakao kering yang berkualitas tinggi.

\section{KESIMPULAN}

1. Biji kakao kering di Flores dan Lembata baik yang terfermentasi maupun yang tidak terfermentasi terkontaminasi oleh lima jenis jamur yakni : Aspergillus flavus, Aspergillus parasiticus, Aspergillus niger, Aspergillus fumigatus dan Mucor sp. 
Emilia: Isolasi dan identifikasi jamur penghasil mikotoksin pada biji kakao kering yang dihasilkan di Flores-Lembata

2. Total Populasi jamur pada biji kakao kering di Flores dan Lembata yang tidak terfermentasi berkisar antara 50 x $10^{2} \mathrm{cfu} / \mathrm{g}$ sampai $130 \times 10^{2} \mathrm{cfu} / \mathrm{g}$, sedangkan total populasi jamur pada biji kakao kering terfermentasi di Flores dan Lembata berkisar antara $140 \times 10^{2} \mathrm{cfu} / \mathrm{g}$ sampai $320 \times 10^{2}$ $\mathrm{cfu} / \mathrm{g}$.

\section{Ucapan Terima Kasih}

Pada kesempatan ini penulis ingin mengucapkan terima kasih kepada semua pihak yang telah membantu dengan caranya masing-masing dalam melengkapi tulisan ini.

\section{DAFTAR PUSTAKA}

Anonim. 2007. Discussion paper on ochratoxin A in cocoa. Codex Alimentarius Commission, Codex Committee on Food Additives and Contaminants, First session. Beijing, China (16-20 April 2007, CX/CF07/1/19).

Badan Pengawasan Obat dan Makanan. 2004. Status regulasi cemaran dalam produk pangan. Buletin Keamanan Pangan, $6: 4-5$.

Badan Pusat Satatistik NTT. 2011. Nusa Tenggara Timur dalam Angka.NTT.

Badrun, M. 1991. Program Pengembangan Kakao di Indonesia.Prosiding Komperensi Nasional Kakao III, Medan. Buku 2 : 1-9.

Bucheli.P., I. Meyer, A. Pittet, G. Vuataz, and R.Viani. 1998. Industrial Storage of Green Robusta Coffee under Tropical Condition and Its Impact on Raw Material Quality and Ochratoxin A Content. J Agric Food Chem. (46):4507 - 4511.

Cowan dan Steel's. 1974. Manual of Medical Bacteria Revised by S.T. Cowan. Second Edition.Cambridge University Press London. New York. Melbourne.

Cotty, P. J. 1997. Aflatoxin-producing potential of communities of Aspergillus section Flavi from cotton producing areas in the United States, Mycol. Res. 101(6) : 698-704.

FAO. 1997. Worldwide Regulations for Mycotoxins for 1995. A conpendium food and nutrition paper No. 64 Rome. Pp. 10-15.

Firdausil, A.B., Nasriati, A. Yani. 2008. Teknologi Budidaya Kakao. Balai Besar Pengkajian dan Pengembangan Teknologi Pertanian. Badan Penelitian dan Pengembangan Pertanian.

Fristo, C.C. 2009.Pengaruh Penyimpanan Biji Kakao Hasil Fermentasi dan Non Fermentasi terhadap Pertumbuhan Aspergillus sp. dan Kandungan Senyawa Aflatoksin.Skripsi. Program Studi Teknologi Hasil Pertanian. Fakultas Teknologi Pertanian. Universitas Andalas.

Hastono, S. 1995. Kapang Toksigenik dari Pakan, Komponen Pakan dan Hasil Pertanian Lain. Kumpulan Makalah Lengkap KONAS PMKI I dan Temu Ilmiah. Hal.123-133. 